\title{
FAKTOR- FAKTOR YANG MEMPENGARUHI PENILAIAN MAHASISWA ATAS PERILAKU TIDAK ETIS AUDITOR SERTA TINGKAT KETERTARIKAN BELAJAR DAN BERKARIR DI BIDANG AKUNTANSI
}

\author{
Reni Yendrawati \\ Fakultas Ekonomi Universitas Islam Indonesia Yogyakarta \\ reni@fe.uii.ac.id \\ Gaby Marcellia \\ Fakultas Ekonomi Universitas Islam Indonesia Yogyakarta \\ gabymarcellia@yahoo.co.id
}

\begin{abstract}
This research is replicated from research paper that has been done by Comunale (2006). The purpose of this research is to analyze the effect of ethic orientation, gender and knowledge on accounting profession and accounting scandal on accounting student's assessment towards unethical auditor and its' effect on student's interests in accounting field and profession as auditor in accounting firm. The hypothesis testing shows that the occuring accounting scandals do not have significant effects in accounting student's perception towards unethical auditor. However, there are factors that may affect student's willingness and interest to study accounting and to work as auditor in accounting firm. The evidence cloncluded two accepted hypothesis: student's knowledge on accounting profession and accounting scandal effect on declining interest to study accounting and the student's idealism which may contribute to their falling interest on working as auditor in accounting firm.
\end{abstract}

Keywords: idealism, perception, study, profession.

\section{PENDAHULUAN}

Etika merupakan pemikiran kritis yang membicarakan ukuran baik buruknya perilaku manusia. Berdasarkan etika inilah seseorang dapat berperilaku etis maupun tidak etis yang akan berdampak pada lingkungan di mana ia berada. Begitu banyak perilaku tidak etis yang dilakukan seseorang terlihat dalam bentuk skandal/kecurangan/penyimpangan/penyelewengan yang dilakukan seseorang dalam profesinya menimbulkan suatu krisis yang disebut dengan krisis etis profesional. Bidang profesi akuntansi tidak luput dari skandal yang pada akhirnya dapat menyebabkan krisis etis profesional. Skandal akuntansi yang 
terjadi mungkin telah mempengaruhi perbedaan persepsi akuntan, pendidik, dan mahasiswa akuntansi dilihat dari gender (Hunt et al, 2009). Persaingan dan kesempatan yang muncul dapat menjadi penyebab timbulnya suatu pelanggaran kode etik profesi akuntan. Seperti yang dilakukan oleh anggota tim auditor BPK (Badan Pemeriksa Keuangan), Khairiansyah Salman yang menjebak Mulyana W Kusumah dengan sejumlah uang untuk mengungkap indikasi terjadinya korupsi di tubuh Komisi Pemilihan Umum (KPU) pada tahun 2005 (Syarifudin, 2012).

Banyak penelitian yang merujuk bagaimana aspek etis sebagai bagian dari pendidikan akuntansi untuk membekali mahasiswa agar memiliki kesadaran etis dalam menjalankan profesinya (Mulawarman dan Ludigdo, 2010). Perilaku etis yang dilakukan seseorang akan memberikan dampak baik bagi lingkungan di mana ia berada. Perilaku tidak etis dapat memberikan dampak buruk baik bagi mereka yang sudah berkecimpung di dalam lingkungan atau profesi tersebut maupun mereka yang sedang mempersiapkan diri untuk terjun ke dalamnya (Dewi, 2010).

Perilaku tidak etis merupakan suatu perilaku menyimpang yang dilakukan oleh seseorang demi mencapai suatu tujuan tertentu. Begitu banyak perilaku tidak etis yang dilakukan seseorang terlihat dalam bentuk skandal, kecurangan, maupun pelanggaran yang dilakukan seseorang dalam profesinya. Jenis kelamin tidak berdampak pada perilaku etis (Lung, 2010).

Bidang profesi akuntansi yang tidak luput dari skandal pada akhirnya dapat menyebabkan krisis etis profesional. Perhatian yang ditujukan kepada profesi akuntansi ini disebabkan oleh beberapa faktor diantaranya adalah pelanggaran terhadap standar dan aturan yang berlaku terkait dengan kode etik profesi akuntansi.

Perilaku tidak etis dapat muncul di saat seorang auditor melakukan pemeriksaan terhadap laporan keuangan suatu perusahaan, seperti krisis etika yang terjadi pada profesi akuntansi dengan adanya temuan bahwa auditor ikut terlibat dalam menyetujui kecurangan pelaporan keuangan yang dilakukan oleh perusahaan-perusahaan besar seperti Enron, WorldCom, Tyco dan lain sebagainya (Dewi, 2010).

Di Indonesia, kasus skandal akuntansi bukanlah hal yang baru. Salah satu kasus yang pernah ramai diberitakan adalah keterlibatan $10 \mathrm{KAP}$ (Kantor Akuntan Publik) di Indonesia dalam praktik kecurangan keuangan. KAP-KAP tersebut ditunjuk untuk mengaudit 37 bank sebelum terjadinya krisis keuangan pada tahun 1997. Hasil audit mengungkapkan bahwa laporan keuangan bankbank tersebut sehat. Namun saat krisis menerpa Indonesia, bank-bank tersebut kolaps karena kinerja keuangannya yang sangat buruk. Dalam investigasi yang dilakukan pemerintah terungkap bahwa KAP-KAP tersebut terlibat dalam praktik kecurangan akuntansi. 
Dalam konteks kode etik profesi, auditor telah melakukan tindakan/perilaku tidak etis. Apa yang harus dilakukan auditor BPK adalah bahwa dengan standar teknik dan prosedur pemeriksaan, auditor BPK harus bisa secara cermat, objektif, dan benar mengungkapkan bagaimana aliran dana tersebut masuk ke KPU dan bagaimana dana tersebut dikeluarkan atau dibelanjakan. Dengan teknik dan prosedur yang juga telah diatur dalam profesi akuntan, hal-hal negatif pasti akan terungkap, termasuk jika dugaan korupsi telah terjadi (Syarifudin, 2012).

Berbagai skandal yang terjadi dengan keterlibatan auditor didalamnya telah menimbulkan reaksi dalam bentuk opini maupun persepsi pada diri mahasiswa. Mereka yang sedang mempelajari akuntansi dan bersiap untuk meneruskan studi ataupun karirnya di bidang akuntansi tentunya akan mempertimbangkan kembali rencana masa depan mereka tersebut.

Penelitian ini merupakan replikasi dari penelitian yang dilakukan oleh Comunale et al (2006) yang berjudul "Professional Ethical Crises: A Case Study of Accounting Majors". Dalam penelitiannya, Comunale menggunakan variabel orientasi etis, gender, umur, dan pengetahuan mengenai skandal akuntansi dan profesi akuntansi untuk mengetahui reaksi mahasiswa akuntansi terkait dengan opini mereka terhadap auditor dan corporate manager serta tingkat ketertarikan belajar dan berkarir di bidang akuntansi.

Dalam penelitian ini, peneliti kembali menguji reaksi mahasiswa terhadap krisis etis profesional yang dilihat dari dua aspek orientasi etis, yaitu mahasiswa yang memiliki orientasi idealisme dan mahasiswa yang memiliki orientasi relativis. Sikap idealis ini diartikan sebagai sikap yang tidak memihak dan terhindar dari berbagai kepentingan. Mahasiswa yang memiliki idealisme yang tinggi cenderung akan bertindak tegas terhadap segala tindakan yang merugikan orang lain. Sedangkan mahasiswa yang memiliki orientasi relativis cenderung lebih melihat keadaan sekitar sebelum pada akhirnya merespon suatu kejadian yang melanggar etika.

Peneliti ini juga menggunakan variabel gender untuk mengetahui apakah gender dapat mempengaruhi persepsi mahasiswa setelah terjadinya berbagai skandal akuntansi yang ada. Di Indonesia isu gender masih menjadi hal yang menarik untuk diuji oleh para peneliti terkait dengan dunia akuntan. Penelitian yang dilakukan Mutmainah (2006) menunjukkan bahwa mahasiswa perempuan jurusan akuntansi lebih mempertimbangkan permasalahan etis daripada mahasiswa laki-laki.

Dalam penelitian sebelumnya sampel diambil dari perguruan tinggi negeri di Amerika Serikat, sehingga dianggap kurang mewakili opini atau pendapat mahasiswa akuntansi secara keseluruhan. Hal ini menjadi menarik untuk diteliti kembali di Indonesia karena untuk melihat apakah skandal akuntansi yang terjadi juga akan memberikan dampak yang sama terhadap mahasiswa di Indonesia khususnya mahasiswa akuntansi di Universitas Islam Indonesia yang 
tidak hanya dari lokasi dan kultur yang berbeda, namun berlandaskan syariat Islam sehingga diharapkan memiliki sudut pandang yang berbeda terkait dengan penilaian mereka atas perilaku tidak etis auditor serta tingkat ketertarikan belajar dan berkarir di bidang akuntansi. Selanjutnya penelitian ini akan mengangkat kasus skandal akuntansi yang terjadi di Indonesia. Selain itu peneliti juga mempersempit karir di bidang akuntansi hanya sebagai auditor. Dengan demikian akan sangat menarik untuk mengetahui beragam reaksi mahasiswa akuntansi di Indonesia mengenai salah satu pelanggaran perilaku etis yang melibatkan profesi akuntansi di Indonesia.

Berbagai skandal yang terjadi dengan keterlibatan auditor didalamnya telah menimbulkan reaksi dalam bentuk opini maupun persepsi pada diri mahasiswa. Mereka yang sedang mempelajari akuntansi dan bersiap untuk meneruskan studi ataupun karirnya di bidang akuntansi tentunya akan mempertimbangkan kembali rencana masa depan mereka tersebut. Dilihat dari praktik kecurangan yang terjadi secara langsung maupun tidak langsung ternyata menimbulkan reaksi yang membentuk suatu opini maupun persepsi di dalam diri mahasiswa terhadap profesi di bidang akuntansi, baik sebagai akuntan maupun sebagai seorang manajer.

Tujuan penelitian ini adalah untuk menguji dan menganalisis pengaruh orientasi etika (idealisme dan relativisme), gender, dan pengetahuan tentang profesi akuntansi dan skandal terhadap persepsi mahasiswa akuntansi atas perilaku tidak etis auditor serta ketertarikan mereka untuk belajar akuntansi dan bekerja sebagai seorang auditor.

\section{KAJIAN PUSTAKA}

Dalam berbagai literature, penilaian mahasiswa dalam bentuk persepsi terhadap perilaku tidak etis auditor serta bagaimana tingkat ketertarikan belajar dan berkarir di bidang akuntansi ini bisa dipengaruhi oleh banyak hal, seperti penelitian yang dilakukan oleh Comunale, et al., (2006) yang hasilnya menunjukkan bahwa tingkat idealisme tinggi yang dimiliki mahasiswa memberi pengaruh negatif terhadap persepsi mereka atas perilaku auditor, namun tidak mempengaruhi minat mereka untuk belajar dan berkarir di bidang akuntansi. Lain lagi dengan penelitian Dewi (2010) yang menunjukkan relativisme dan tingkat pengetahuan yang dimiliki mahasiswa akuntansi memberikan pengaruh terhadap persepsi mereka atas perilaku tidak etis auditor. Berbeda dengan penelitian yang dilakukan Mutmainah (2006) yang memfokuskan penelitiannya pada pengaruh gender terhadap pertimbangan etis mahasiswa. Berdasarkan penjelasan di atas, penelitian ini menggunakan variabel orientasi etis yang terdiri dari idealisme dan relativisme, gender dan tingkat pengetahuan. 


\section{Idealisme}

Idealisme adalah tingkat di mana individu berkaitan dengan kesejahteraan bagi yang lain. Individu yang memiliki idealisme tinggi merasa mengganggu orang lain selalu dapat dihindarkan. Individu yang berorientasi secara idealis tidak akan memilih perilaku negatif yang dapat mengganggu orang lain. Dengan kata lain idealisme merupakan karakterikstik orientasi etika yang mengacu pada kepedulian seseorang terhadap kesejahteraan orang lain dan berusaha untuk tidak merugikan orang lain (Sugianto, 2011). Jadi, Idealisme mengukur sikap/ perilaku seseorang untuk tidak melanggar nilai-nilai etika dan menimbulkan kerugian terhadap orang lain (Comunale, 2006).

Sikap idealisme juga diartikan sebagai sikap tidak memihak dan terhindar dari berbagai kepentingan. Seseorang dengan idealisme rendah atau pragmatis, mengakui adanya prinsip moral tersebut dapat mengakibatkan konsekuensi negatif. Mereka merasakan bahwa beberapa kejahatan sering diperlukan untuk mencapai manfaat secara keseluruhan (Forsyth,1992).

\section{Relativisme}

Relativisme adalah sikap penolakan individu terhadap nilai-nilai etika dalam mengarahkan perilaku etis (Sugianto, dkk, 2011). Relativisme mengukur suatu sikap seseorang yang mengarah ke prinsip moral dan aturan secara universal. Relativisme menolak prinsip dan aturan moral secara universal dan merasakan bahwa tindakan moralitas tersebut tergantung pada individu dan situasi yang dilibatkan Forsyth (1992).

Individu yang memiliki tingkat relativisme tinggi menganggap bahwa tindakan moral tergantung pada situasi dan sifat individu yang terlibat, sehingga ketika bertindak tidak bermoral terhadap individu lain mereka akan mempertimbangkan situasi dan kondisi individu tersebut dibandingkan prinsip etika yang telah dilanggar. Oleh karena itu, individu dengan tingkat relativisme tinggi cenderung menolak gagasan mengenai kode moral. Individu dengan relativisme rendah hanya akan mendukung tindakan-tindakan moral yang berdasar pada prinsip, norma, ataupun hukum universal.

Relativisme etis sendiri merupakan teori bahwa suatu tindakan dapat dikatakan etis atau tidak benar atau salah, tergantung pada pandangan masyarakat itu sendiri (Forsyth, 1992). Hal ini disebabkan oleh teori ini meyakini bahwa tiap individu maupun kelompok memiliki keyakinan etis yang berbeda.

\section{Gender}

Umar (1999) mengungkapkan berbagai pengertian gender antara lain:

1. Di dalam Women's Studies Encyclopedia dijelaskan bahwa gender adalah suatu konsep kultural yang berupaya membuat pembedaan (distinction) dalam hal peran, perilaku, mentalitas, dan karakteristik emosional antara laki-laki dan perempuan yang berkembang di masyarakat. 
2. Gender juga diartikan lebih dari sekedar pembedaan antara laki-laki dan perempuan dilihat dari konstruksi budaya. la menekannya sebagai konsep analisis (an analytic concept) yang dapat digunakan untuk menjelaskan sesuatu.

Berdasarkan definisi di atas dapat disimpulkan bahwa gender merupakan suatu konsep analisis yang digunakan untuk mengidentifikasi perbedaan laki-laki dan perempuan dilihat dari sudut non-biologis, yaitu dari aspek sosial, budaya maupun psikologis.

\section{Tingkat Pengetahuan}

Pengetahuan pada hakikatnya merupakan segenap apa yang kita ketahui tentang suatu objek tertentu termasuk ilmu. Jadi, ilmu merupakan bagian dari pengetahuan yang diketahui oleh manusia disamping berbagai pengetahuan lainnya (Suriasumantri, 2007). Dalam Kamus Bahasa Indonesia, pengetahuan diartikan sebagai segala sesuatu yang diketahui berkenan dengan hal tertentu (http://kamusbesarbahasaindonesia.org)

Pada penelitian ini pengetahuan yang dimaksud adalah pengetahuan mengenai profesi di bidang akuntansi dan informasi mengenai kasus Mulyana W Kusumah (anggota KPU) yang dijebak oleh Khairiansyah Salman (tim auditor BPK) untuk melakukan penyuapan terhadap auditor tersebut demi mengungkapkan indikasi korupsi di tubuh KPU.

Tingkat pengetahuan dan informasi yang dimiliki mahasiswa akan mempengaruhi persepsi mereka terhadap skandal tersebut. Mahasiswa yang memiliki tingkat pengetahuan dan informasi yang tinggi mengenai skandal maka akan membantu mereka untuk dapat memberikan persepsi maupun tanggapan terhadap krisis etis yang melibatkan profesi auditor tersebut. Namun dengan banyaknya informasi yang diperoleh dari media dapat menimbulkan persepsi negatif mahasiswa terhadap profesi akuntansi.

Mahasiswa yang kurang mendapat informasi mengenai skandal auditor BPK akan berpersepsi biasa saja. Mereka tidak terlalu mengetahui duduk persoalannya sehingga mereka akan tetap memberikan opini positif terhadap bidang profesi akuntansi. Pada akhirnya tingkat pengetahuan dan informasi yang dimiliki oleh mahasiswa akan mempengaruhi keputusan mereka untuk belajar dan berkarir di bidang akuntansi.

\section{Penelitian Terdahulu}

Penelitian yang dilakukan oleh Comunale et al (2006) menunjukkan bahwa mahasiswa akuntansi pada dasarnya memiliki pengetahuan yang cukup baik mengenai skandal etis yang terjadi. Namun mereka tidak memiliki banyak pengetahuan mengenai bidang profesi akuntansi. Tingkat idealisme tinggi yang dimiliki mahasiswa memberi pengaruh negatif terhadap persepsi mereka atas 
perilaku auditor, namun tidak mempengaruhi minat mereka untuk belajar dan berkarir di bidang akuntansi. Mahasiswi akuntansi menunjukkan tingkat yang tinggi terhadap ketertarikan belajar dan berkarir di bidang akuntansi.

Penelitian yang dilakukan Nugroho (2008) menunjukkan bahwa orientasi etis, gender, umur, dan tingkat pengetahuan mahasiswa akuntansi terhadap skandal akuntansi yang telah terjadi tidak mempengaruhi persepsi mereka atas perilaku tidak etis auditor serta tidak mempengaruhi minat belajar dan berkarir mereka di bidang akuntansi.

Penelitian Dewi (2010), menunjukkan bahwa relativisme dan tingkat pengetahuan yang dimiliki mahasiswa akuntansi memberikan pengaruh terhadap persepsi mereka atas perilaku tidak etis auditor.

Penelitian yang dilakukan Mutmainah (2006) menunjukkan bahwa mahasiswa perempuan jurusan akuntansi lebih mempertimbangkan permasalahan etis daripada mahasiswa laki-laki. Dari tiga disiplin ilmu (akuntansi, hukum, dan tehnik informatika), diketahui mahasiswa akuntansi lebih mampu menilai suatu dilema etis dibandingkan mahasiswa jurusan lain.

Penelitian Darsinah (2005) menunjukkan adanya perbedaan yang signifikan dalam sensitivitas etis antara mahasiswa laki-laki dan perempuan.

Penelitian Djadjang (2006) menunjukkan bahwa auditor perempuan memiliki tingkat sensitifitas etika lebih tinggi dibanding auditor pria.

Hipotesis yang diajukan dalam penelitian ini adalah sebagai berikut:

H1a: mahasiswa akuntansi dengan idealisme tinggi akan menilai tindakan auditor lebih tegas.

H1b: mahasiswa akuntansi dengan idealisme tinggi akan memperlihatkan sedikit ketertarikan belajar akuntansi karena adanya skandal akuntansi.

H1c: mahasiswa akuntansi dengan idealisme tinggi akan kurang tertarik mengejar karir sebagai auditor karena adanya skandal akuntansi.

H2a: mahasiswa akuntansi dengan relativisme tinggi akan menilai tindakan auditor lebih toleran.

H2b: mahasiswa akuntansi dengan relativisme tinggi akan memperlihatkan sedikit ketertarikan belajar akuntansi karena adanya skandal akuntansi.

H2c: mahasiswa akuntansi dengan relativisme tinggi akan kurang tertarik mengejar karir sebagai auditor karena adanya skandal akuntansi.

H3a: mahasiswi akuntansi akan menilai auditor lebih tegas.

H3b: mahasiswi akuntansi akan memperlihatkan sedikit ketertarikan belajar akuntansi karena skandal akuntansi.

H3c: mahasiswi akuntansi akan kurang tertarik mengejar karir sebagai auditor karena adanya skandal akuntansi.

$\mathrm{H} 4 \mathrm{a}$ : pengetahuan yang tinggi tentang profesi akuntansi dan skandal akuntansi yang terjadi berpengaruh terhadap besarnya penurunan persepsi mahasiswa akuntansi terhadap perilaku auditor. 
$\mathrm{H} 4 \mathrm{~b}$ : pengetahuan yang tinggi tentang profesi akuntansi dan skandal akuntansi yang terjadi akan berpengaruh terhadap besarnya penurunan minat mahasiswa terhadap kuliah akuntansi.

$\mathrm{H} 4 \mathrm{c}$ : pengetahuan yang tinggi tentang profesi akuntansi dan skandal akuntansi yang terjadi akan berpengaruh terhadap besarnya penurunan minat mahasiswa akuntansi terhadap ketertarikan untuk mengejar karir sebagai auditor.

\section{Kerangka Penelitian}

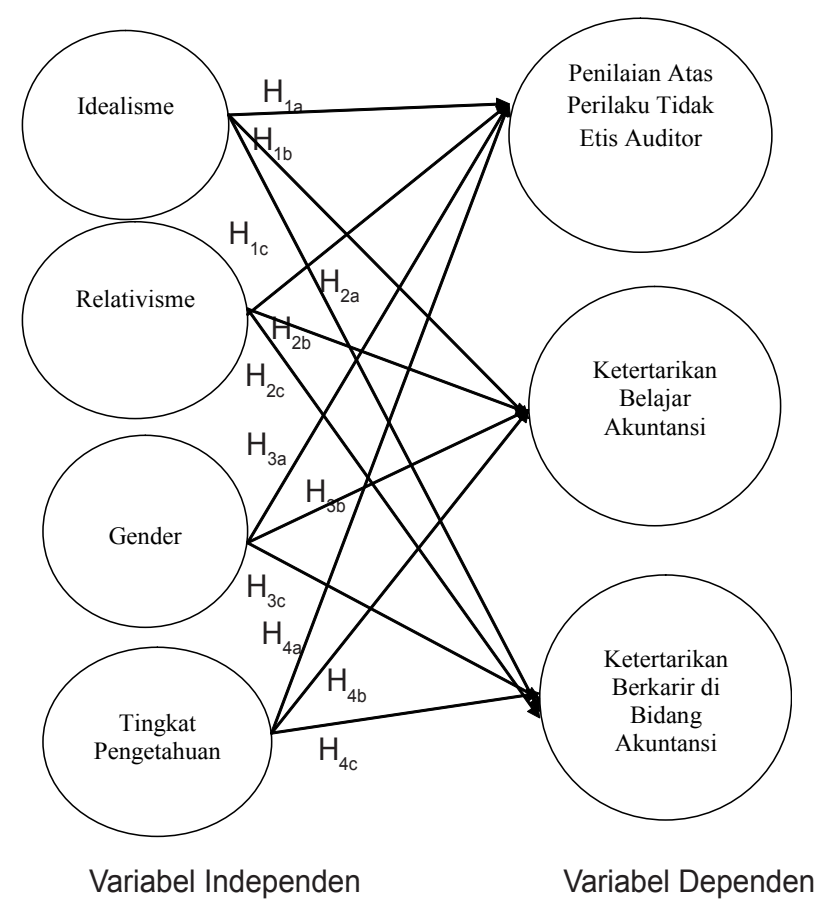

Gambar 1. Kerangka Penelitian

\section{METODE PENELITIAN}

Populasi dalam penelitian ini adalah seluruh mahasiswa jurusan akuntansi Universitas Islam Indonesia Yogyakarta. Metode pengambilan sampel dengan menggunakan metode Convenience Sampling. Jumlah sampel yang digunakan dalam penelitian ini didapatkan dengan menggunakan rumus Slovin. Pengumpulan data menggunakan kuesioner. Sebelum dilakukan uji hipotesis terlebih dahulu peneliti melakukan uji statistik deskriptif, uji reliabilitas, uji validitas, 
dan uji asumsi klasik yang terdiri atas tiga pengujian, yaitu uji normalitas, uji multikolinieritas dan uji heteroskedastisitas.

Metode statistik yang digunakan untuk menguji hipotesis adalah dengan menggunakan regresi berganda (multiple regression) karena untuk menguji pengaruh variabel independen yaitu Tot_Idealisme, Tot_Relativisme, Gender, dan Tot_Know terhadap variabel dependen yaitu Pers_Acct, IntMajAcc, dan IntPubAcc. Selain itu, metode regresi berganda dipandang mampu menghubungkan satu variabel dependen dengan beberapa variabel independen dalam suatu model prediktif tunggal. Model prediksi yang digunakan dalam penelitian ini dapat dilihat pada model pengujian hipotesis di bawah ini:

$$
\begin{aligned}
& \text { Pers_Acct }=a+b_{1} \text { Tot_ } I+b_{2} \text { Tot_Rel }+b_{3} G+b_{4} \text { Tot_Know }+e \\
& \text { IntMajAcc }=a+b_{1} \text { Tot_ } I+b_{2} \text { Tot_Rel }+b_{3} G+b_{4} \text { Tot_Know }+e \\
& \text { IntPubAcc }=a+b_{1} \text { Tot_I }+b_{2} \text { Tot_Rel }+b_{3} G+b_{4} \text { Tot_Know }+e
\end{aligned}
$$

Keterangan:

Pers_Acct $=$ dampak faktor-faktor independen terhadap persepsi mahasiswa atas perilaku tidak etis auditor

IntMajAcc = dampakfaktor-faktor independen terhadap ketertarikan responden untuk belajar akuntansi

IntPubAcc $=$ dampakfaktor-faktor independen terhadap ketertarikan responden untuk bekerja sebagai auditor

Tot_ $=$ total skor dari tingkat idealisme

Tot_Rel $=$ total skor dari tingkat relativisme

$\mathrm{G}=$ gender/jenis kelamin (dummy)

Tot_Know = jumlah jawaban yang benar untuk mengukur pengetahuan responden

a $\quad=$ konstanta

$\mathrm{b} \quad=$ koefisien regresi

e $\quad=$ standar error

Pengujian ini dilakukan dengan menggunakan program SPSS. Hipotesis diuji pada tingkat signifikansi $(\alpha=5 \%)$.

\section{HASIL ANALISIS}

\section{Regresi Berganda}

Seluruh hasil pengujian persamaan regresi berganda ditunjukkan sebagai berikut:

(1) Pers_Acct $=0,861+0,429$ Tot_I+0,013Tot_Rel+0,166G $+0,000$ Tot_Know $+e$

(2) IntMajAcc $=3,256-0,015$ Tot_l-0,063Tot_Rel-0,018G-0,292Tot_Know + e

(3) IntPubAcc $=3,314-0,347$ Tot_I-0,134Tot_Rel+0,132G+0,083Tot_Know+e 


\section{Uji F Statistik}

Hasil uji model dapat dilihat pada Tabel 1, Tabel 2, dan Tabel 3.

Tabel 1. Uji Model Opini terhadap Auditor

\begin{tabular}{|c|c|c|c|c|c|c|}
\hline \multicolumn{7}{|c|}{ AllOVA } \\
\hline Model & & $\begin{array}{c}\text { Sum of } \\
\text { Squares }\end{array}$ & $d f$ & Mean Square & $\mathrm{F}$ & Sig. \\
\hline 1 & Regression & 6.604 & 4 & 1.651 & 2.762 & $.030^{\mathrm{a}}$ \\
\hline & Residual & 86.656 & 145 & .598 & & \\
\hline & Total & 93.260 & 149 & & & \\
\hline
\end{tabular}

a. Predictors: (Constant), Know, G, Rel, I

b. Dependent Variable: Pers_Acct

Tabel 2.Uji Model Opini terhadap Ketertarikan Belajar Akuntansi

\begin{tabular}{|ll|r|r|r|r|c|}
\hline \multicolumn{1}{|c|}{ ANOVA } \\
Model & & $\begin{array}{c}\text { Sum of } \\
\text { Squares }\end{array}$ & \multicolumn{1}{c|}{ df } & Mean Square & \multicolumn{1}{c|}{$\mathrm{F}$} & Sig. \\
\hline 1 & Regression & 4.371 & 4 & 1.093 & 3.127 & $.017^{\text {a }}$ \\
& Residual & 50.677 & 145 & .349 & & \\
& Total & 55.048 & 149 & & & \\
\hline
\end{tabular}

a. Predictors: (Constant), Know, G, Rel, I

b. Dependent Variable: IntMajAcc

Tabel 3. Uji Model Opini terhadap Ketertarikan Bekerja sebagai Auditor

\section{ANOVA}

\begin{tabular}{|cc|r|r|r|r|r|}
\hline Model & $\begin{array}{r}\text { Sum of } \\
\text { Squares }\end{array}$ & \multicolumn{1}{c|}{ df } & Wean Square & F & Sig. \\
\hline $1 \quad$ Regressio & 4.595 & 4 & 1.149 & 2.759 & $.030^{\circ}$ \\
& Residual & 60.365 & 145 & .416 & & \\
Total & 64.960 & 149 & & & \\
\hline
\end{tabular}

a.Predictors: (Constant), Know, G, Rel, I

b. Dependent Variable: IntPubAcc

\section{Uji Koefisien Determinasi $\left(\mathbf{R}^{2}\right)$}

Hasil uji koefisien determinasi dapat dilihat pada Tabel 4, Tabel 5, dan Tabel 6.

Tabel 4. Hasil Uji Koefisien Determinasi

Model Summary

\begin{tabular}{|l|r|r|r|r|}
\hline Model & R & R Square & $\begin{array}{c}\text { Adjusted } \\
\text { R Square }\end{array}$ & $\begin{array}{r}\text { Std. Error of } \\
\text { the Estimate }\end{array}$ \\
\hline 1 & $.266^{\mathrm{a}}$ & .071 & .045 & .77307 \\
\hline
\end{tabular}

a. Predictors: (Constant), Know, G, Rel, I

b. Dependent Variable: Pers_Acct 
Tabel 5. Hasil Uji Koefisien Determinasi

Model Summaryb

\begin{tabular}{|l|r|r|r|r|}
\hline Model & $\mathrm{R}$ & $\mathrm{R}$ Square & $\begin{array}{c}\text { Adjusted } \\
\mathrm{R} \text { Square }\end{array}$ & $\begin{array}{c}\text { Std. Error of } \\
\text { the Estimate }\end{array}$ \\
\hline 1 & $.282^{\mathrm{a}}$ & .079 & .054 & .59118 \\
\hline
\end{tabular}

a. Predictors: (Constant), Know, G, Rel, I

b. Dependent Variable: IntMajAcc

Tabel 6. Hasil Uji Koefisien Determinasi

Model Summary

\begin{tabular}{|l|r|r|r|r|}
\hline Model & R & R Square & $\begin{array}{c}\text { Adjusted } \\
\text { R Square }\end{array}$ & $\begin{array}{c}\text { Std. Error of } \\
\text { the Estimate }\end{array}$ \\
\hline 1 & $.266^{a}$ & .071 & .045 & .64522 \\
\hline
\end{tabular}

a. Predictors: (Constant), Know, G, Rel, I

b. Dependent Variable: IntPubAcc

\section{Uji Signifikansi Parameter Individual (Uji t Statistik)}

Hasil uji signifikansi parameter individual dapat dilihat pada Tabel 7, Tabel 8, dan Tabel 9.

Tabel 7. Hasil Uji Signifikansi Parameter Individual

Coefficient?

\begin{tabular}{|c|c|c|c|c|c|c|c|c|}
\hline \multirow{2}{*}{\multicolumn{2}{|c|}{ Mode }} & \multicolumn{2}{|c|}{$\begin{array}{l}\text { Unstandardized } \\
\text { Coefficients }\end{array}$} & \multirow{2}{*}{\begin{tabular}{|c|} 
Standardized \\
Coefficients
\end{tabular}} & \multirow[b]{2}{*}{$t$} & \multirow[b]{2}{*}{ Sig. } & \multicolumn{2}{|c|}{ ollinearity Statistic } \\
\hline & & B & Std. Error & & & & Tolerance & VIF \\
\hline 1 & (Constant & .861 & .679 & & 1.268 & .207 & & \\
\hline & 1 & .429 & .144 & .274 & 2.987 & .003 & .764 & 1.309 \\
\hline & Rel & .013 & .162 & .006 & .079 & .937 & .954 & 1.049 \\
\hline & $G$ & .166 & .133 & .105 & 1.247 & .214 & .912 & 1.096 \\
\hline & Know & .000 & .147 & .000 & .002 & .999 & .848 & 1.179 \\
\hline
\end{tabular}

a.Dependent Variable: Pers_Acct

Tabel 8. Hasil Uji Signifikansi Parameter Individual

Coefficients

\begin{tabular}{|c|c|c|c|c|c|c|c|c|}
\hline \multirow{2}{*}{\multicolumn{2}{|c|}{ Mode }} & \multicolumn{2}{|c|}{$\begin{array}{c}\text { Unstandardized } \\
\text { Coefficients }\end{array}$} & \multirow{2}{*}{\begin{tabular}{|c|} 
Standardized \\
Coefficients \\
Beta \\
\end{tabular}} & \multirow[b]{2}{*}{$t$} & \multirow[b]{2}{*}{ Sig. } & \multicolumn{2}{|c|}{ olline arity Statistic } \\
\hline & & $\mathrm{B}$ & Btd. Error & & & & olerance & VIF \\
\hline \multirow[t]{5}{*}{1} & (Constant & 3.256 & .519 & & 6.274 & .000 & & \\
\hline & 1 & -.115 & .110 & -.095 & -1.046 & .297 & .764 & 1.309 \\
\hline & Rel & .063 & .124 & -.041 & -.504 & .615 & .954 & 1.049 \\
\hline & $G$ & .018 & .102 & -.015 & -.178 & .859 & .912 & 1.096 \\
\hline & Know & -.292 & .113 & -.224 & -2.587 & .011 & .848 & 1.179 \\
\hline
\end{tabular}

a.Dependent Variable: IntMajAco 
Tabel 9. Hasil Uji Signifikansi Parameter Individual

Coefficients

\begin{tabular}{|c|c|c|c|c|c|c|c|c|}
\hline \multirow{2}{*}{\multicolumn{2}{|c|}{ Model }} & \multicolumn{2}{|c|}{\begin{tabular}{|c|} 
Unstandardized \\
Coefficients
\end{tabular}} & \multirow{2}{*}{\begin{tabular}{|c|} 
tandardized \\
Foefficients \\
Beta
\end{tabular}} & \multirow[b]{2}{*}{$t$} & \multirow[b]{2}{*}{ Sig. } & \multicolumn{2}{|c|}{ ollinearity Statistic } \\
\hline & & $\mathrm{B}$ & ttd. Error & & & & oleranca & VIF \\
\hline 1 & (Constar & 3.314 & .566 & & 5.852 & .000 & & \\
\hline & I & -.347 & .120 & -.266 & -2.899 & .004 & .764 & 1.309 \\
\hline & Rel & -.134 & .136 & -.081 & -.990 & .324 & .954 & 1.049 \\
\hline & G & -.132 & .111 & -.100 & -1.188 & .237 & .912 & 1.096 \\
\hline & Know & .083 & .123 & .059 & .676 & .500 & .848 & 1.179 \\
\hline
\end{tabular}

aDependent Variable: IntPubAcc

\section{PEMBAHASAN}

\section{Regresi Berganda}

Berdasar model regresi berganda pada halaman sebelumnya, dapat dijelaskan hubungan variabel independen dengan variabel dependen sebagai berikut:

Persamaan (1). Konstanta sama dengan 0,861 memberikan pengertian bahwa jika idealisme, relativisme, gender, dan pengetahuan sama dengan nol, besarnya persepsi mahasiswa terhadap perilaku tidak etis auditor adalah 0,861. Jika idealisme mengalami peningkatan, persepsi mahasiswa terhadap perilaku tidak etis auditor juga mengalami peningkatan, dengan asumsi variabel independen lain konstan. Jika relativisme mengalami peningkatan, persepsi mahasiswa terhadap perilaku tidak etis auditor juga mengalami peningkatan, dengan asumsi variabel independen lain konstan. Jika gender mengalami peningkatan, persepsi mahasiswa terhadap perilaku tidak etis auditor juga mengalami peningkatan, dengan asumsi variabel independen lain konstan. Jika pengetahuan tentang profesi akuntansi dan skandal akuntansi mengalami peningkatan, persepsi mahasiswa terhadap perilaku tidak etis auditor juga mengalami peningkatan, dengan asumsi variabel independen lain konstan.

Persamaan (2). Konstanta sama dengan 3,256 memberikan pengertian bahwa jika idealisme, relativisme, gender, dan pengetahuan tentang profesi akuntansi dan skandal akuntansi sama dengan nol, besarnya ketertarikan mahasiswa untuk belajar akuntansi adalah sebesar 3,256 . Jika idealisme mengalami penurunan, ketertarikan mahasiswa untuk belajar akuntansi mengalami peningkatan, dengan asumsi variabel independen lain konstan. Jika relativisme mengalami penurunan, ketertarikan mahasiswa untuk belajar akuntansi mengalami peningkatan, 
Persamaan (3). Konstanta sama dengan 3,314 memberikan pengertian bahwa jika idealisme, relativisme, gender dan pengetahuan tentang profesi akuntansi dan skandal akuntansi sama dengan nol, besarnya ketertarikan mahasiswa untuk bekerja sebagai auditor adalah sebesar 3,314. Jika idealisme mengalami penurunan, ketertarikan mahasiswa untuk bekerja sebagai auditor mengalami peningkatan, dengan asumsi variabel independen lain konstan. Jika relativisme mengalami penurunan, ketertarikan mahasiswa untuk bekerja sebagai auditor mengalami peningkatan, dengan asumsi variabel independen lain konstan. Jika gender mengalami peningkatan, ketertarikan mahasiswa untuk bekerja sebagai auditor juga mengalami peningkatan, dengan asumsi variabel independen lain konstan. Jika pengetahuan mahasiswa tentang profesi akuntansi dan skandal akuntansi meningkat, ketertarikan mahasiswa untuk bekerja sebagai auditor juga mengalami peningkatan, dengan asumsi variabel independen lain konstan.

\section{Uji F Statistik}

Berdasarkan Tabel 1 nilai $\mathrm{F}$ hitung pada kelompok mahasiswa akuntansi sebesar 2,762 dan signifikansi sebesar 0,030 atau di bawah nilai signifikansi 0,05 . Hal ini berarti bahwa variabel tingkat pengetahuan, idealisme, relativisme, dan gender berpengaruh terhadap variabel persepsi mahasiswa atas perilaku tidak etis auditor. Tabel 2 didapat nilai $F$ hitung sebesar 3,127 dengan tingkat probabilitas signifikansi jauh lebih kecil dari 0,05 yaitu sebesar 0,17 . Hasil tersebut menunjukkan adanya pengaruh idealisme, relativisme, pengetahuan, dan gender terhadap penilaian mahasiswa akuntansi terhadap ketertarikan mahasiswa akuntansi untuk belajar akuntansi. Terakhir, pada Tabel 3 diketahui nilai $F$ hitung pada kelompok mahasiswa akuntansi sebesar 2,759 dan signifikansi sebesar 0,030 atau di bawah nilai signifikan 0,05 . Hal ini berarti bahwa variabel tingkat idealisme, relativisme, pengetahuan, dan gender berpengaruh terhadap variabel ketertarikan mahasiswa akuntansi untuk bekerja sebagai seorang auditor.

\section{Uji Koefisien Determinasi $\left(\mathbf{R}^{2}\right)$}

Pada Tabel 4 diketahui besarnya nilai adjusted $\mathrm{R}^{2}$ adalah 0,045 . Ini berarti bahwa dengan nilai adjusted $R^{2}$ sebesar $4,5 \%$ variabilitas variabel independen 
dalam hal ini adalah idealisme, relativisme, gender, dan pengetahuan berpengaruh terhadap variabel penilaian mahasiswa atas perilaku tidak etis auditor. Pada Tabel 5 besarnya nilai adjusted $R^{2}$ adalah 0,054 , ini berarti bahwa dengan nilai adjusted sebesar $5,4 \%$ variabilitas variabel independen dalam hal ini adalah idealisme, relativisme, gender, dan pengetahuan berpengaruh terhadap variabel ketertarikan mahasiswa akuntansi untuk belajar akuntansi. Terakhir, pada tabel 6 diketahui besarnya nilai adjusted $\mathrm{R}^{2}$ adalah 0,045 ini berarti bahwa dengan nilai adjusted sebesar $4,5 \%$ variabilitas variabel independen dalam hal ini adalah idealisme, relativisme, gender, dan pengetahuan berpengaruh terhadap variabel ketertarikan mahasiswa akuntansi untuk bekerja sebagai auditor.

\section{Uji Signifikansi Parameter Individual (Uji t Statistik)}

Berdasarkan Tabel 7, dapat diketahui bahwa variabel idealisme, relativisme, gender, dan pengetahuan tidak berpengaruh secara signifikan terhadap penilaian mahasiswa akuntansi atas perilaku tidak etis auditor karena memiliki nilai signifikansi di atas 0,05 yaitu 0,937 untuk variabel relativisme, 0,214 untuk variabel gender, dan 0,999 untuk variabel pengetahuan. Pada tabel 8 walaupun variabel idealisme memiliki nilai signifikansi kurang dari 0,05 namun variabel ini memiliki arah yang positif sebesar 0,429 . Selanjutnya pada Tabel 9 dapat diketahui bahwa variabel gender memiliki arah negatif senilai $-0,292$ dengan signifikansi sebesar 0,011 sehingga dapat disimpulkan bahwa tingkat pengetahuan yang tinggi yang dimiliki mahasiswa mengenai skandal akuntansi dan profesi akuntansi memiliki pengaruh dalam penurunan ketertarikan mahasiswa terhadap kuliah akuntansi. Hal ini menunjukkan bahwa penurunan minat ini mungkin dikarenakan mereka menganggap bahwa ilmu akuntansi turut berperan dalam terjadinya skandal akuntansi sehingga mengakibatkan mereka enggan untuk terlibat dalam skandal tersebut dikarenakan bidang ilmu yang mereka pelajari. Hal ini berakibat menurunkan motivasi mereka untuk belajar akuntansi. Terakhir, hasil uji t statistik untuk ketertarikan bekerja sebagai auditor dapat diketahui bahwa variabel idealisme memiliki arah negatif senilai $-0,347$ dengan signifikansi 0,004 sehingga dapat disimpulkan bahwa mahasiswa akuntansi dengan idealisme tinggi akan kurang tertarik mengejar karir sebagai auditor karena adanya skandal akuntansi. Skandal akuntansi yang terjadi ternyata mampu mempengaruhi ketertarikan mahasiswa akuntansi untuk bekerja sebagai auditor. Hal ini dikarenakan mahasiswa akuntansi FE UII tidak lagi menganggap bekerja sebagai seorang auditor menjadi sebuah prestise maupun jalur karir yang sangat sesuai untuk mengimplementasikan ilmu akuntansi yang mereka peroleh. Terdapat kemungkinan mahasiswa akuntansi FE UII yang memiliki idealisme yang tinggi lebih tertarik untuk menjadi dosen, banker, pegawai di bagian keuangan sebuah perusahaan atau yang lain. 


\section{PENUTUP}

\section{Kesimpulan}

Berdasarkan hasil analisis dan pembahasan, dapat ditarik kesimpulan bahwa tidak ada variabel yang dapat menunjukkan pengaruh yang signifikan terhadap persepsi mahasiswa akuntansi FE UII atas tindakan auditor dalam skandal akuntansi. Tidak sensitifnya mahasiswa akuntansi terhadap hal ini dikarenakan bahwa mereka belum sepenuhnya memahami aturan-aturan yang telah ditetapkan oleh organisasi atau profesi yang tidak diperoleh dalam perkuliahan dan belum dihadapkan dalam situasi yang benar-benar riil, sehingga hal ini akan mempengaruhi mereka dalam menjustifikasi etis atau tidaknya suatu perbuatan. Namun pengolahan data juga memberikan hasil bahwa variabel pengetahuan menunjukkan pengaruh yang signifikan terhadap menurunnya minat dan ketertarikan mahasiswa akuntansi FE UII untuk belajar akuntansi serta variabel idealisme menunjukkan pengaruh yang signifikan terhadap menurunnya minat dan ketertarikan mahasiswa akuntansi FE UII untuk bekerja sebagai seorang auditor.

\section{Keterbatasan Penelitian}

Penelitian ini memiliki keterbatasan-keterbatasan antara lain objek penelitian hanya berasal dari mahasiswa akuntansi di satu universitas sehingga tidak dapat mencerminkan karakteristik seluruh mahasiswa akuntansi yang ada. Selanjutnya dari hasil analisis yang telah dilakukan, variabel-variabel independen dalam penelitian ini memiliki pengaruh yang kecil terhadap variabel dependen penelitian, kemungkinan masih ada faktor-faktor lain yang dapat mempengaruhi persepsi, minat serta ketertarikan mahasiswa akuntansi sehingga dapat dijadikan variabel independen. Terakhir, penelitian ini mengangkat kasus mengenai pelanggaran kode etik yang telah lama terjadi, yakni delapan tahun yang lalu.

\section{Saran}

Berdasarkan hasil penelitian, maka diajukan saran untuk peneliti berikutnya sebagai berikut:

1. Menambah objek penelitian tidak hanya melibatkan satu universitas;

2. Meneliti variabel lain selain variabel-variabel yang sudah diteliti misalnya pengalaman magang atau bekerja di suatu entitas, ataupun berbagai aspek lain dari orientasi etis karena menurut hasil penelitian ini variabel independen yang ada hanya memiliki pengaruh yang kecil terhadap variabel dependen penelitian;

3. Mengangkat kasus perilaku tidak etis yang terkini atau baru terjadi sehingga permasalahan yang diangkat lebih dimengerti mahasiswa. 


\section{DAFTAR PUSTAKA}

Anonim, Definisi Pengetahuan, http://kamusbahasaindonesia.org/, Diakses 3 Maret 2014.

Anonim, Reaksi terhadap Skandal Akuntansi, http://library.gunadarma.ac.id. Diakses 3 Maret 2014.

Comunale, et. al. (2006), Professional Etchical Crises: ACase Study of Accounting Majors. Managerial Auditing Journal, Vol 21, No. 6, 636-656.

Darsinah (2005), Perbedaan Sensitivitas Etis Ditinjau dari Disiplin IImu dan Gender. Tesis, Fakultas Ekonomi Universitas Diponegoro.

Dewi, H. N. (2010), Persepsi Mahasiswa atas Perilaku Tidak Etis Akuntan. Skripsi. Fakultas Ekonomi Universitas Diponegoro Semarang.

Djadjang, S (2006), Analisis Intensitas Moral dan Orientasi Etis. Bulletin Penelitian No.09.

Forsyth, D. Judging (1992), The Morality of Business Practices: The Influence of Personal Moral Philosophics, Journal of Business Ethics, Vol. 11.

Hunt, S. C, Robert, C. I. A., Antony, F. dan Marie, T. P. C. (2009), The Effect of Gender and Knowledge On Students Impression of Accountants in The Post - Enron Era, Journal of Business and Economics Research, Vol. 7.

Lung, C. K (2010), Attitude Toward Business Ethics: Examining The Influence of Religiously, Gender and Education Levels, International Journal of Marketing Studies, Vol. 2.

Mulawarman, A. D. dan U. Ludigdo (2010), Metamorfosis Kesadaran Etis Holistis Mahasiswa Akuntansi: Implementasi Pembelajaran Etika Bisnis dan Profesi Berbasis Integrasi IESQ, Jurnal Akuntansi Multiparadigma, Vol. 1, No. 3.

Mutmainah, S, Studi tentang Perbedaan Evaluasi Etis, Intensi Etis (Ethical Intention) dan Orientasi Etis dilihat dari Gender dan Disiplin IImu: Potensi Rekruitmen Staf Profesional pada Kantor Akuntan Publik. Simposium Nasional Akuntansi 9 Padang, 23-26 Agustus 2006.

Nugroho, B (2008), Faktor-Faktor yang Mempengaruhi Penilaian Mahasiswa Akuntansi atas Tindakan Auditor dan Corporate Manager dalam Skandal Akuntansi serta Tingkat Ketertarikan Belajar dan Berkarier di Bidang Akuntansi. Tesis. Magister Akuntansi Universitas Diponegoro. 
Sugianto, dkk (2011), Hubungan Orientasi Etika, Komitmen Profesional, Sensitivitas Etis dengan Whistleblowing Perspektif Mahasiswa Akuntansi. Diakses tanggal 1 Oktober 2013, http://pasca.unhas. ac.id.

Suriasumantri, J. S (2007), Filsafat IImu, Sebuah Pengantar Populer, Pustaka Sinar Harapan, Jakarta.

Syarifudin, Muchammad, Kasus Mulyana dalam Perspektif Etika. Retrieved September 28, 2012, from Warta Warga. Diakses tanggal 2 Oktovber 2013, http://wartawarga.gunadarma.ac.id.

Umar, Nasarudin (1999), Argumen Kesetaraan Gender perspektif Al Quran, Jakarta, Paramadina. 
